\title{
Greening as compensation to production of environmental public goods: how do common rules have an influence at local level? The case of durum wheat in Italy
}

Francesco Diotallevi ${ }^{1}$, Emanuele Blasi ${ }^{2^{*}}$ and Silvio Franco ${ }^{3}$

\footnotetext{
* Correspondence: e.blasi@unitus.it ${ }^{2}$ Department for Innovation in Biological, Agro-food and Forest systems (DIBAF), Università degli Studi della Tuscia, Via S.Camillo de Lellis snc), Viterbo 01100, Italy Full list of author information is available at the end of the article
}

\begin{abstract}
The promotion of sustainability is envisaged by the new Common Agricultural Policy (CAP) as a major issue for future policies in the agro-food sector, in line with the Europe 2020 Strategy. In this context, "greening" ecological payments have been conceived as a tool to encourage European farms towards the adoption of environmentally friendly practices. Since the new CAP became law, at least 30\% of the national budget of direct payments is tied to the respect of three main ecological commitments by farmers managing 10 or more hectares of arable land, i.e. crop diversification, maintaining permanent grassland and maintaining the so called "ecological focus areas".

The present research focuses on the possible effects of the greening instrument, by evaluating the impact of this tool in different Italian areas, specialized in the durum wheat cultivation. The objectives of the analysis are to evaluate the extent and features of the impact of greening in three case study areas and to discuss the likely implications in a policy-effectiveness perspective.

Thus, an empirical analysis has been carried out in order to evaluate the impact of greening in three case study areas with a strong specialization in wheat production, located in the North, Centre and South of Italy.The results have been compared across the case studies and with other quantitative and qualitative studies carried out in different contexts.

The results show that the impact of greening may be different even in areas with the same productive specialization. Namely, greening deeply impacts on the durum wheat cultivation area located in the South of Italy, while it seems to have a very marginal effect on the other two areas. Thus, greening has a strongly differentiated impact both at the farm and at the territorial level, at least for the Italian durum wheat production. Basing on these first results, the setting of specific solutions to rebalance the effects of greening on the durum wheat sector is envisaged, as allowed by the present regulatory framework, in order to avoid an over-diversification in the impacts of the greening measure among different Italian regions.
\end{abstract}

Keywords: Greening; CAP; Durum Wheat; Policies Impacts

\section{Springer}

(C) 2015 Diotallevi et al. This is an Open Access article distributed under the terms of the Creative Commons Attribution License (http://creativecommons.org/licenses/by/4.0), which permits unrestricted use, distribution, and reproduction in any medium, provided the original work is properly credited. 


\section{Background}

The latest Common Agricultural Policy (CAP) reform, the fifth since 1992, has become operational from January 2014. The future of European agriculture has been long debated; now we need to get definite answers (De Castro 2006; Garzon, 2006; De Castro et al., 2012).

During CAP negotiations, the EU Parliament reiterated its role in the co-decision process, and asked the Council to be more flexible on still "open" issues. However, at the same time, national governments have opposed renegotiating the terms of the latest compromises. Many meetings took place in Brussels, late in 2013, focusing entirely on the ultimate definition of the new CAP.

Although the CAP has been approved, the debate is still going on about greening, which is unanimously believed to be one of the real novelties of this policy reform.

Greening has its origins in the European Commission communication of 18 November 2010, in which the need to strengthen the environmental effectiveness of the CAP was greatly emphasised. The European Union had already felt this need since the last programming: in this sense, European rural policy programs, within the context of the second pillar of the CAP, were established in each EU Member State in accordance with these specific outlines, for the funding period 2007-2013 (Adinolfi et al., 2011; Karelakis et al., 2013).

The greening component of direct payments aims at supporting environmental commitments throughout the EU, by means of introducing additional payments for public goods (e.g., subtraction of $\mathrm{CO}_{2}$, soil protection, water drainage and quality). These payments are mandatory for Member States (MS) and available to all farmers who voluntarily respect the required environmental commitments. The commitments are relatively easy to apply, as they consist in a kind of "reinforced" cross-compliance. In this perspective, greening arises as remuneration for the production of public goods, in line with the aim of the Europe 2020 Strategy. The debate on this issue, in particular on its implementation, is very intense (Cooper et al., 2009; Garrod, 2009; Hart and Baldock, 2011).

The present research estimates the possible effects of the greening instrument of the new CAP. In particular, it evaluates the impact of this measure in different Italian areas that are specialized in the durum wheat cultivation. More specifically, the following research questions are defined:

1. What are the greening influences on the durum wheat sector in Italy?

2. Can the same policy criteria achieve comparable outcomes in areas with a wide structural and climatic heterogeneity?

In this sense, the paper may be viewed as an interesting empirical exercise, and it also finds similarities with quantitative and qualitative studies implemented in various contexts (e.g., Heinrich, 2012; Westhoek et al., 2012; Brown and Jones, 2013; Chatellier and Guyomard 2013; Czekaj et al. 2013; Vanni and Cardillo 2013a; Cimino et al., 2014).

The authors believe that the qualitative considerations expressed on the compromise reached by the EU Council of Agriculture can be summarised and evaluated only through quantitative application, providing a measure of the net effect that the measures will cause in very different productive and climatic contexts (Povellato, 2012).

Being Italy one of the leading durum wheat producers in the EU, as well as a substantial user of raw durum wheat for transformation into products (semolina and, above all, pasta) which represent a major component of traditional Italian food exports, the assessment of the consequences for the durum wheat sector is of particular interest. EU interventions for durum wheat have always been associated with and strongly oriented towards "traditional" 
production areas. However, with the new reform, the direct support will completely change. Consequently, there is an urgent need to understand how firms working in these production systems can keep maintaining their activity and the present working levels.

\section{Greening in the CAP context}

The CAP 2014-2020 negotiation process has introduced several innovations, from the definition of the "active farmer" to the rules of the direct payments, both of which will highly affect the distribution of payments among farmers and regions in the next years. One crucial step in this sense was the agreement, taken in June 2013, between the Council, the European Parliament and the European Commission, which has completely rewritten the rules of the CAP (from a system of direct payments to market regulation in the single Common Market Organization - CMO, Rural Development, etc.).

The last months have been decisive for the CAP to be applied at national level: the main features of the new CAP are subsidiarity and flexibility, so that MS have large margins for corrective actions. Governments and Regions are committed to adopt many decisions, such as regionalisation, the choice of the homogeneous regions, the optional support and/ or the definition of the upper limits to payments (namely, for basic payments, redistributed payments for the first hectares, fewer favoured areas, young farmers, coupled payments, small farmers), the criteria for allocation of titles, the management of national reserves, the threshold for minimum payments etc.

In general, the implementation of the new CAP should follow these criteria:

- increased equity (distribution of direct payments among MS, regions and farmers without "historical references");

- strengthening of farmers' position in the food chain;

- greening: MS, regions and farmers will face the challenges of sustainability and climate change with simple measures of proven effectiveness. Between 2014 and 2020, more than 100 billion euro will be invested to help agriculture meeting the challenge of soil and water quality, biodiversity and climate change;

- increased effectiveness and transparency: means for supporting research, innovation and knowledge will be doubled. The coordination with other European funds about the program of rural development will be improved. The four-axes approach will be replaced by a more flexible strategic approach at national and regional level. A simplified supporting scheme for small farmers will be available on the base of the choice of the MS. Moreover, most of the information on CAP aid, except for very few amounts, will be made public.

In the new CAP, the direct payments system will be more equitable, with convergence not only between MS but also within them. In addition, greening payments will be introduced to comply with certain sustainable agricultural practices. This means that a substantial proportion of the subsidies will be devoted to reward farmers for their provision of public goods respecting the environment.

All payments will depend on compliance with several environmental rules. Table 1 shows the list of all payments inside the CAP reform. 
Table 1 Scheme of payments of new CAP

\begin{tabular}{|c|c|c|c|}
\hline \multirow{2}{*}{$\begin{array}{l}\text { Payments } \\
\text { Basic Payment }\end{array}$} & \multicolumn{2}{|c|}{ Type Distribution of funds } & \multirow{2}{*}{$\begin{array}{l}\text { Conditions } \\
\text { Basic conditionality }\end{array}$} \\
\hline & Mandatory & Max $70 \%$ & \\
\hline $\begin{array}{l}\text { Redistributive Payment } \\
\text { (first hectares) }\end{array}$ & Optional & Max $30 \%$ & For first 30 hectares \\
\hline Greening & Mandatory & $30 \%$ & $\begin{array}{l}\text { Best agricultural practices for } \\
\text { climate and environment }\end{array}$ \\
\hline $\begin{array}{l}\text { Payment for areas with natural } \\
\text { constraints/LFA }\end{array}$ & Optional & $\operatorname{Max} 5 \%$ & Location of disadvantaged areas \\
\hline Payments for young farmers & Mandatory & $\operatorname{Max} 2 \%$ & Age less than 40 years \\
\hline Coupled Payment & Optional & Max $15 \%$ & $\begin{array}{l}\text { Specific productions, except } \\
\text { tobacco and potatoes }\end{array}$ \\
\hline Payment for small farmers & Optional & Max $10 \%$ & $\begin{array}{l}\text { Small farmers' application/for } \\
\text { small farmers }\end{array}$ \\
\hline
\end{tabular}

Source: authors' elaboration on CAP reform document, 2013

Each payment is subject to a set of rules:

a. Basic Payment Scheme (BPS): MS will devote $70 \%$ of their direct payments national envelope to the new Basic Payment Scheme.

b. Redistributive Payment: for the first hectares, whereby farmers can take up to $30 \%$ of the national envelope and redistribute it to farmers on their first 30 hectares (or up to average farm size if over $30 \mathrm{ha}$ ). This will have a significant redistributive effect. A further possible option is to apply a maximum payment per hectare.

c. Young Farmers: in order to encourage generational renewal, the Basic Payment awarded to new young farmers (aged under 40) should be topped up by an additional $25 \%$ for the first five years of installation. This will be funded by up to $2 \%$ of the national envelope and will be compulsory for all MS. This measure is intended in addition to other measures available for young farmers under Rural Development Programs.

d. Small Farmers Scheme: a farmer claiming support may decide to participate in the Small Farmers Scheme and thereby receive an annual payment fixed by the MS between $500 €$ and $1,250 €$, regardless of farm size.

e. "Coupled" option: in order to address the potentially adverse effects of internal convergence for specific sectors in certain regions as well as to take account of existing conditions, MS will have the option of providing limited amounts of coupled payments (i.e., payments linked to specific products).

f. Areas with Natural Constraints (ANCs) and Less Favoured Areas (LFAs): MS (or regions) may grant additional payments for areas with natural constraints (as defined under Rural Development rules) of up to $5 \%$ of the national envelope. This is optional and does not affect the ANC/LFA options available under Rural Development.

g. Greening: in addition to the Basic Payment Scheme, payments per hectare will be provided to farms as a reward for their commitment to agricultural practices, which are proved to be beneficial for the climate and the environment. MS will use the $30 \%$ of their national envelope to finance these measures. This is compulsory, and failure to respect the specific requirements will result in penalties that are higher than the greening payments (125\% more). The three basic measures are:

- maintaining permanent grassland; 
- crop diversification: when arable land exceeds 10 hectares, a minimum of 2 crops should be cultivated or, when it exceeds 30 hectares, the minimum is 3 crops (the main crop may cover at most $75 \%$ of arable land, and the two main crops the $95 \%$ );

- maintaining an "ecological focus area" (EFA) of $5 \%$ of the arable area, at least for farms covering more than 15 hectares (excluding permanent grassland). EFAs are to be understood as field margins, hedges, trees, fallow land, landscape features, biotopes, buffer strips, and afforested areas.

In order to avoid penalisations for those firms which already address environmental and sustainability issues, the reform considers a "greening equivalency", i.e. when environmentally beneficial practices are already being applied, they are used on behalf of the greening requirements (e.g., organic farms).

To summarize, it may be stated that, with the new CAP reform, policy-makers recognise the important role played by agriculture in a sustainable perspective, with a view to inclusive and intelligent growth.

\section{Greening impact in Italy}

The sector of durum wheat in Italy

In the latest revision of European agricultural policy, the management of arable lands has been a central point of discussion between MS and the Commission. Since the Mac Sharry's reform, the issue of commodity's production has been addressed with incisive interventions: first by ensuring the protection of the farmers through measures to support the production and protect the markets, then moving into the limitation of production through strong measures such as set-aside and decoupling.

This strategic line of CAP expenditure, justified by environmental and social goals, as well as the need for a regulation of the market, was launched in Agenda 2000 and applied with the Fischler's reform. With the introduction of the decoupled single payment system and the gradual disappearance of the CMOs, significant changes in the rules and in the distribution of direct payments has occurred, both between MS and sectors. The latest proposals keep recommending a less distort redistribution of payments between MS. Coherently with this context, the rules of greening should follow the same perspective. In this sense, greening interventions aim to develop standard rules that overlook the context of the single MS as a result of the negotiation process.

In this section, in order to assume the impact scenarios of the new CAP, and specifically, of the greening crop diversification rule compared to the durum wheat sector in Italy, a snapshot of the production of cereals in Italy is provided.

At the national level, the total wheat surface occupies $28 \%$ of the entire arable land and $54 \%$ of the areas for the cultivation of cereals. Durum wheat is the main cereal cultivated in Italy, which is a leading country in the world, with 1.4 million hectares and a production of about 4 million tonnes (Diskussionspapiere and Department für Agrarökonomie und Rurale 2010).

Thus, to identify the impact of the reform on the durum wheat sector id crucial in the Italian and Mediterranean context. A descriptive overview of the sector will be given through the analysis of national data divided by region (NUTS 1). First, we report the trends observed in the last four censuses relating to surface distribution (Table 2) and the number of firms (Table 3). 
Table 2 Land devoted to durum wheat in Italian macro-regions (hectares): 1982-2010

\begin{tabular}{lllllllll}
\hline & 1982 & & 1990 & & 2000 & & 2010 \\
\hline North-western & 6.471 & $0.3 \%$ & 11.798 & $0.6 \%$ & 8.204 & $0.5 \%$ & 23.402 & $1.6 \%$ \\
North-eastern & 28.708 & $1.5 \%$ & 60.512 & $3.3 \%$ & 30.138 & $1.8 \%$ & 94.816 & $6.7 \%$ \\
Central & 202.476 & $10.9 \%$ & 299.33 & $16.4 \%$ & 393.982 & $23.2 \%$ & 315.237 & $22.2 \%$ \\
South & 995.982 & $53.8 \%$ & 926.633 & $50.8 \%$ & 853.792 & $50.2 \%$ & 657.996 & $46.4 \%$ \\
Insular & 618.785 & $33.4 \%$ & 527.158 & $28.9 \%$ & 413.364 & $24.3 \%$ & 327.656 & $23.1 \%$ \\
Italy & $1,852,423$ & & $1,825,430$ & & $1,699,480$ & & $1,419,106$ & \\
\hline
\end{tabular}

Source: authors' elaboration on Italian Census Data

We observe that, in recent years, the production in the North Italy has increased, both in terms of surfaces and companies. The central and southern areas of Italy are still the most suited for the durum wheat cultivation, concentrating $92 \%$ of the cultivated areas - $70 \%$ in only 5 regions (NUTS 2 - Apulia, Sicily, Basilicata, Marche and Tuscany). Such heterogeneity also emerges when we analyse the distribution of production in different areas, with the central and southern areas reaching the $86 \%$ of the total.

In the previous CAP reform this situation, typical for the durum wheat cultivation, has motivated the Italian decision of activating the "surface - aid" instrument (Art. 68 Reg. 73/2009). Through this measure for durum wheat, in the central and southern regions, as well as in the islands, the nature of "specific" production has been recognized as able to preserve the quality of traditional products.

In Table 4, the average yield per hectare and the area under durum wheat are shown (farm average); from these data we can observe that, while the utilized agricultural area (UAA) of durum wheat is fairly uniform nationwide, the yield reaches almost a double level in the north regions with respect to the south and the islands.

The differentiation of the durum wheat cultivation among Italian regions is also evident from the economic point of view. This is true both in terms of incidence on the production value (VP) and considering the gross margin level of the crop (Table 5).

In conclusion, it is likely that such territorial heterogeneity of the durum wheat sector could be the origin of profound differences in the impact of the new criteria for the distribution of the aid to the arable areas. The same happens with regards to the constraints of crop diversification provided as part of greening. To study this aspect into details, in the next section a more thorough analysis on a NUTS 3 regional scale is carried out.

Table 3 Number of farms with durum wheat cultivation in Italian macro-regions: 1982-2010

\begin{tabular}{lllllllll}
\hline & 1982 & & 1990 & & 2000 & & 2010 \\
\hline North-western & 3.370 & $0.7 \%$ & 3.507 & $0.9 \%$ & 2.474 & $0.8 \%$ & 3.118 & $1.5 \%$ \\
North-eastern & 7.366 & $1.6 \%$ & 12.504 & $3.0 \%$ & 6.476 & $2.1 \%$ & 11.600 & $5.7 \%$ \\
Central & 36.373 & $7.7 \%$ & 45.625 & $11.1 \%$ & 47.887 & $15.7 \%$ & 31.818 & $15.7 \%$ \\
South & 248.652 & $52.9 \%$ & 221.298 & $53.9 \%$ & 163.827 & $53.8 \%$ & 105.892 & $52.2 \%$ \\
Insular & 174.093 & $37.1 \%$ & 127.284 & $31.0 \%$ & 83.630 & $27.5 \%$ & 50.362 & $24.8 \%$ \\
Italy & 469.854 & & 410.218 & & 304.294 & & 202.79 & \\
\hline
\end{tabular}

Source: authors' elaboration on Italian Census Data 
Table 4 Production, average yield and farm size of durum wheat in Italian macro-regions

\begin{tabular}{llll}
\hline & $\begin{array}{l}\text { Production } \\
\text { (tons,000) }\end{array}$ & $\begin{array}{l}\text { Yield } \\
\text { (tons/hectares) }\end{array}$ & $\begin{array}{l}\text { UAA per farm } \\
\text { (hectares) }\end{array}$ \\
\hline North-western & 116 & 5.37 & 8.17 \\
North-eastern & 431 & 5.12 & 7.51 \\
Central & 1.022 & 3.56 & 9.91 \\
South & 1.485 & 2.83 & 6.21 \\
Insular & 900 & 2.64 & 6.51 \\
Italy & 3.953 & 3.14 & 7.00 \\
\hline
\end{tabular}

Source authors' elaboration on Italian Census Data and ISTAT Database, 2010

Characterization of the study areas

Moving from the framework sketched in the previous section, an empirical analysis has been carried out in order to compare and to discuss the impact of greening in different Italian regions. In particular, three case study areas, each one identified by two provinces with a strong specialization in wheat production, has been selected:

1. Bologna and Ferrara (BO-FE) in northern Italy;

2. Ancona and Macerata (AN-MC) in central Italy;

3. Foggia and Bari (FG-BB) in southern Italy.

In the first step of the study, some context indicators were collected to describe the sectorial characteristics of the three areas. The desk analysis, performed with data from the last ISTAT agricultural census, aims to describe the main structural traits of agriculture and to evaluate the presence of wheat crops in farms of different dimension.

The number of farms and the total UAA are significantly different among the case study areas (Table 6). Indeed, the FG-BA area shows a higher presence of small farms with an average dimension of 7.0 hectares, while the BO-FE area is characterized by a texture of medium size farms whose average dimension of 18.9 hectares is considerably higher than the typical Italian farm (7.9 hectares). The AN-MC are is in an intermediate position with an average UAA of 11.5 hectares per farm.

Looking at the presence of wheat cultivation in the three areas (Table 7) other differences arise. The main one concerns the variety of wheat cultivated: durum wheat is largely dominant both in AN-MC and FG-BA areas, while it assumes the same extent of common wheat in the BO-FE area. Another issue to be noticed is the level of crop specialization, which is significantly higher in FG-BA area (exceeding the $60 \%$ of total arable land) and lower in BO-FE area, where the crop only covers one third of the total arable land.

Table 5 Economic results of durum wheat cultivation in crops specialized farms

\begin{tabular}{lll}
\hline & VP durum wheat/NP crops & Gross margin (€/hectares) \\
\hline North-western & $11.3 \%$ & 746 \\
North-eastern & $10.8 \%$ & 787 \\
Central & $34.3 \%$ & 533 \\
South & $40.6 \%$ & 471 \\
Insular & $39.4 \%$ & 626 \\
\hline
\end{tabular}

Source: authors' elaboration on Italian FADN Database, 2010 
Table 6 Number of farms and total UAA for classes of UAA in the three study areas

\begin{tabular}{llllllll}
\hline \multicolumn{7}{c}{$<$} & \multicolumn{2}{l}{$10-30$ hectares } & \multicolumn{3}{l}{$>$ hectares } & Total \\
\hline Number of farms & & & & & & & \\
BO-FE & 10.855 & $58.6 \%$ & 5.1 & $27.5 \%$ & 2.582 & $13.9 \%$ & 18.537 \\
AN-MC & 17.169 & $76.9 \%$ & 3.475 & $15.6 \%$ & 1.691 & $7.6 \%$ & 22.335 \\
FG-BA & 92.232 & $84.4 \%$ & 11.834 & $10.8 \%$ & 5.201 & $4.8 \%$ & 109.267 \\
Total UAA & & & & & & & \\
BO-FE & 46.062 & $13.2 \%$ & 86.775 & $24.8 \%$ & 217.26 & $62.1 \%$ & 350.1 \\
AN-MC & 56.891 & $22.2 \%$ & 57.471 & $22.4 \%$ & 141.7 & $55.3 \%$ & 256.062 \\
FG-BA & 209.091 & $27.4 \%$ & 199.89 & $26.2 \%$ & 354.45 & $46.4 \%$ & 763.423 \\
\hline
\end{tabular}

Source: authors' elaboration on Italian Census Data, 2010

Therefore, despite the common specialization in wheat cultivation, the three selected areas show a different structural and productive characterization. This situation, as pointed out in the previous section, might have generated a differentiated impact of the first pillar policies and, in particular, of greening measures.

To verify this hypothesis a simulation of the greening impact in the three areas has been carried out following the methodological approach described in the next section.

\section{Methods}

The approach adopted to evaluate the impact of greening measures in the three areas specialized in wheat cultivation is structured in four steps.

Step 1. Identification of number of farms and agricultural land potentially interested by greening constraints (only with regard to crop diversification) in the three areas, according to the information provided by the sample of farms included in the Italian FADN (Farm Accountancy Data Network).

Step 2: Assessment of the representativeness of FADN sample with respect to the universe of farms surveyed by the Italian agricultural Census in the three study areas. Considering the general objective of the analysis and the sampling methodology of Italian FADN database, which ensures a statistical representativeness at regional level (Abitabile and Scardera 2008), the correspondence between the sample and the universe is only evaluated in a qualitative way. So, if the relative presence and dimension of durum wheat cultivation in the farms sampled by FADN and in farm surveyed by Census is "sufficiently" similar, it can be acceptable to expand the results of step 1 to the whole areas through steps 3 and 4 .

Table 7 Presence (hectares) of wheat cultivation in the three study areas

\begin{tabular}{llll}
\hline & BO-FE & AN-MC & FG-BA \\
\hline Durum wheat & 45.358 & 86.236 & 279.915 \\
Common (Soft) wheat & 53.612 & 5.116 & 9.548 \\
Wheat (total) & 98.970 & 91.352 & 289.463 \\
Arable land & 298.186 & 205.598 & 472.132 \\
UAA & 350.100 & 256.062 & 763.423 \\
Wheat/Arable land & $33.2 \%$ & $44.4 \%$ & $61.3 \%$ \\
Wheat/UAA & $28.3 \%$ & $35.7 \%$ & $37.9 \%$ \\
\hline
\end{tabular}

Source: authors' elaboration on Italian Census Data, 2010 
Step 3: Generalization of the greening impact, as evaluated at FADN farms level, to the universe of farms in the three study areas;

Step 4: Comparison between gross margin of wheat cultivation and greening payment component in the three areas in order to estimate a rough economic impact of greening constraints both at the level of the farm and on the entire areas considered.

The empirical application of this methodological process is presented in the next section. It should be emphasized that the main objective of the analysis is to underline the different type and level of greening impact in the three areas and to discuss the likely implications in a policy-effectiveness perspective. Differently from other studies carried out on the same topic - see, for example, Rete Rurale Nazionale (2012) and Vanni et al. (2013b), both related to Italian context and based on FADN data - the present analysis does not aim to assess the impact of greening on farmers revenues, rather it attempts to evaluate the extent to which the impact of greening might be different even in areas with the same productive specialization.

For this reason, as pointed out in step 1, only the greening crop diversification has been taken into account; this justifies the failure to explicitly consider the EFA obligations. On the other hand, it should be considered that this aspect of the greening does not appear to have a relevant effect in the Italian agricultural context (Frascarelli, 2014).

\section{Results and Discussion}

The first step of the analysis consists in the identification of FADN sample farms that will be potentially included in the greening measures constraints defined for the crop diversification objective.

As outlined in the first part of the paper, this greening measure disregards farms whose arable land is lower than 10 hectares. Conversely, a farmer must cultivate at least 2 crops when his arable land exceeds 10 hectares and at least 3 crops when his arable land exceeds 30 hectares. The main crop may cover at most $75 \%$ of arable land, and the two main crops at most $95 \%$ of the arable area. So, in the three study areas, all the FADN sample farms with wheat cultivation have been analysed to check if they comply with the crop diversification conditions posed by greening.

Table 8 shows the results of this analysis with respect to the number of farms and the extension of arable land which don't match the requirements of greening.

It is important to notice that the impact is very different between the southern area of FG-BA and the areas located in northern (BO-FE) and central (AN-MC) Italy. In fact, in FG-BA area half of the farms with wheat cultivation and about $60 \%$ of their arable land do not comply with the crops diversification constraint; differently, in the other two areas the level of impact of the greening measure, both for farms and arable land, is about $10 \%$.

This result, that seems to point out a largely spatial heterogeneity in the impact of greening, needs however to be confirmed by expanding the sample to the entire set of farms of the area.

To fit this purpose, the second step of the analysis has been carried out by comparing some significant data between the FADN sample and the Census data in the three study areas (Table 9), with the aim to evaluate the extent to which the evidences found for FADN farms can be transposed to the whole areas considered. 
Table 8 Farms in FADN sample not complying with greening conditions in the study areas

\begin{tabular}{|c|c|c|c|c|c|c|}
\hline & $<10$ hectares & 10-30 hectares & $>30$ hectares & Total & \multicolumn{2}{|c|}{$\begin{array}{l}\text { Out of } \\
\text { greening } \\
\text { conditions }\end{array}$} \\
\hline \multicolumn{7}{|l|}{$\mathrm{BO}-\mathrm{FE}$} \\
\hline Number of farms with wheat cultivation & 50 & 55 & 54 & 159 & 17 & $10.7 \%$ \\
\hline Arable land in farms with wheat cultivation & 277 & 1.032 & 5.655 & 6.963 & 780 & $11.2 \%$ \\
\hline Arable land devoted to wheat cultivation & 183 & 456 & 1.855 & 2.494 & 439 & $17.6 \%$ \\
\hline \multicolumn{7}{|l|}{ AN-MC } \\
\hline Number of farms with wheat cultivation & 45 & 56 & 59 & 160 & 13 & $8.1 \%$ \\
\hline Arable land in farms with wheat cultivation & 272 & 1.02 & 4.886 & 6.178 & 646 & $10.5 \%$ \\
\hline Arable land devoted to wheat cultivation & 164 & 489 & 2.391 & 3.043 & 398 & $13.1 \%$ \\
\hline \multicolumn{7}{|l|}{ FG-BA } \\
\hline Number of farms with wheat cultivation & 27 & 71 & 72 & 170 & 84 & $49.4 \%$ \\
\hline Arable land in farms with wheat cultivation & 161 & 1.387 & 4.349 & 5.897 & 3.51 & $59.6 \%$ \\
\hline Arable land devoted to wheat cultivation & 136 & 1.024 & 2.581 & 3.741 & 2.31 & $61.9 \%$ \\
\hline
\end{tabular}

Source: authors' elaboration on Italian FADN Database, 2010

As it can be observed, the level of agreement between FADN and Census data, with regard to the analysed data, is generally satisfying. In some cases, the number of FADN farms with wheat cultivation is overestimated with respect to the Census, while the percentage of arable land, with both durum and common wheat, is quite similar between the two data sources in all the three areas. It should be noted that no statistical tests

Table 9 Comparison between farms with wheat cultivation in FADN and Census databases

\begin{tabular}{|c|c|c|c|c|}
\hline $\mathrm{BO}-\mathrm{FE}$ & \multicolumn{2}{|c|}{ FADN Database } & \multicolumn{2}{|c|}{ Census Database } \\
\hline Total number of farms & 270 & & 18.462 & \\
\hline Number of farms with durum wheat cultivation & 71 & $26.3 \%$ & 4.301 & $23.3 \%$ \\
\hline Number of farms with common wheat cultivation & 119 & $44.1 \%$ & 6.092 & $33.0 \%$ \\
\hline Arable land (hectares) & 8.062 & & 298.186 & \\
\hline Arable land devoted to durum wheat cultivation (hectares) & 1.023 & $12.7 \%$ & 45.358 & $15.2 \%$ \\
\hline Arable land devoted to common wheat cultivation (hectares) & 1.471 & $18.2 \%$ & 53.612 & $18.0 \%$ \\
\hline \multicolumn{5}{|l|}{ AN-MC } \\
\hline Total number of farms & 224 & & 22.284 & \\
\hline Number of farms with durum wheat cultivation & 154 & $68.8 \%$ & 9.793 & $43.9 \%$ \\
\hline Number of farms with common wheat cultivation & 17 & $7.6 \%$ & 1.376 & $6.2 \%$ \\
\hline Arable land (hectares) & 7.32 & & 205.598 & \\
\hline Arable land devoted to durum wheat cultivation (hectares) & 2.974 & $40.6 \%$ & 86.236 & $41.9 \%$ \\
\hline Arable land devoted to common wheat cultivation (hectares) & 68 & $0.9 \%$ & 5.116 & $2.5 \%$ \\
\hline \multicolumn{5}{|l|}{ FG-BA } \\
\hline Total number of farms & 324 & & 109.185 & \\
\hline Number of farms with durum wheat cultivation & 163 & $50.3 \%$ & 27.275 & $25.0 \%$ \\
\hline Number of farms with common wheat cultivation & 9 & $2.8 \%$ & 1.437 & $1.3 \%$ \\
\hline Arable land (hectares) & 6.941 & & 472.132 & \\
\hline Arable land devoted to durum wheat cultivation (hectares) & 3.715 & $53.5 \%$ & 279.915 & $59.3 \%$ \\
\hline Arable land devoted to common wheat cultivation (hectares) & 26 & $0.4 \%$ & 9.548 & $2.0 \%$ \\
\hline
\end{tabular}

Source: authors' elaboration on Italian FADN Database and Census Data, 2010 
have been applied to verify the effective representativeness of the FADN sample; nevertheless, considering the general objective of the study, this qualitative comparison can be considered sufficient.

Moving from this consideration, it is possible to generalize the results obtained from FADN database to the farms universe with a reasonable level of accuracy. This process, identified by step 3 in the methodology description, consists in applying to the Census data the figures related to the number of farms and the arable land which don't match the greening conditions calculated in Table 8. This output of this calculation is shown in Table 10.

The existence of a large heterogeneity in the impact of greening across Italian areas with a similar productive specialization is evident. While in BO-FE and AN-MC areas relatively few farmers are concerned by crop diversification measures, in FG-BA the whole wheat sector, and hence the local agricultural production, is dramatically influenced by the introduction of greening.

Nevertheless, the objective of greening, and crop diversification in particular, is to move from monoculture towards more ecological crops rotation practices.

In this perspective, it is economically relevant to look at the farmers' choice between committing themselves to the greening crop diversification requirements and giving up part of the direct support to their income. According to an evaluation of the European Commission (based on the original proposal), the greening impact on European farms income is relatively low, 43 euro per hectare on the average (European Commission 2011a, b). Nevertheless, this amount can widely vary depending on local features, crops profitability and structural characteristics of farms (Cardillo et al., 2012).

A broad analysis of this issue may be faced by comparing the amount of the greening share of the payment with the crop gross margin. The general idea is that the higher the gross margin with respect to greening payment, the higher the advantage for farmers in maintaining the monoculture practice.

To evaluate this aspect, the average gross margin of wheat cultivation in the three study areas has been calculated using the FADN database. In Table 11 this gross margin (together with the average yield) is placed side by side with an estimation of the amount of greening payment (Rete Rurale Nazionale 2012); at the moment, indeed, the final value of this payment has still not been established.

By looking at the results, it appears quite evident that greening deeply impacts on the southern area of FG-BA, while it seems to have a very marginal effect on the other two areas. Indeed, the few farmers of BO-FE and AN-MC areas, dealing with crop diversification constraints, may either adapt the crop pattern of their farms to the requirements of greening, or maintaining the current pattern without losing a significant amount of

Table 10 Estimation of greening impact at farm and arable land level in the three areas

\begin{tabular}{llll}
\hline & BO-FE & AN-MC & FG-BA \\
\hline Farms with wheat cultivation out of greening conditions (FADN) & $10.7 \%$ & $8.1 \%$ & $49.4 \%$ \\
Farms with wheat cultivation (Census) & 8.243 & 10.481 & 27.994 \\
Farms with wheat cultivation out of greening conditions (Total) & 881 & 852 & 13.832 \\
Arable land devoted to wheat cultivation out of greening conditions (FADN) & $17.6 \%$ & $13.1 \%$ & $61.9 \%$ \\
Arable land devoted to wheat cultivation (Census) & 98.97 & 91.352 & 289.463 \\
Arable land devoted to wheat cultivation out of greening conditions (Total) & 17.41 & 11.95 & 179.08 \\
\hline Source: authors' elaboration on Italian FADN Database and Census Data, 2010 & & &
\end{tabular}


Table 11 Comparison between wheat gross margin and greening payment in the three areas

\begin{tabular}{llll}
\hline & BO-FE & AN-MC & FG-BA \\
\hline Yield (tons per hectare) & 5.6 & 4.5 & 3.5 \\
Gross margin (€ per hectare) & 650 & 560 & 390 \\
Greening payment (€ per hectare) & 103 & 98 & 134 \\
\hline
\end{tabular}

Source: authors' elaboration on Italian FADN Database, 2010

their margin. The situation for FG-BA area farmers is very different. They are squeezed between technical problems related to crop pattern adjustments and the possible loss of the greening component of payment, which represents more than one third of the gross margin of wheat cultivation.

If we consider the greening impact in a territorial perspective, the difference among the three areas appears even more evident. Under the hypothesis that no changes to the crop patterns are performed by the farmers, and using the results obtained in Table 5, it is possible to estimate the public support loss due to the introduction of the greening measure (Table 12).

Although this is a rough estimate, based on restrictive hypotheses, there is no doubt that greening has a strongly differentiated impact both at the farm and at the territorial level, at least for the Italian wheat production. The question arising, discussed in the conclusions of this paper, is then if greening, in its current version, is a fair measure and if there is a way to preserve, and even to increase, its environmental objective by preventing further worsening of the agriculture condition in marginal areas.

\section{Conclusion}

For a long time, policy makers asked how the direct payments, and their related mechanisms, were to change in order to find a fair methodology for the aid distribution to farmers (Swinnen, 2009). Several estimates of the national ceiling to the Italian farmers have established a fairly clear picture regarding to potential problems, particularly related to the cultivation of durum wheat.

According to a study commissioned by the Italian Minister of Agriculture to the National Rural Network in 2012, the incidence of direct aid on the operative margins of specialized cereal farms in the production of durum wheat varies greatly. Despite a quite common cultivation technique and a stable prices regime for durum wheat, on closer analysis, even within more suitable regions for the cultivation of durum wheat, interesting differences in production, performance and profitability are noticed.

In this perspective, it is necessary to analyse how the new guidelines at the base of the direct payments are able to affect the future perspectives of the durum wheat sector in Italy, given the high diversification of the cultivation areas around Italy.

Table 12 Comparison between farms with wheat cultivation in FADN and Census databases

\begin{tabular}{llll}
\hline & BO-FE & AN-MC & FG-BA \\
\hline Arable land (hectares) & 17.405 & 11.95 & 179.079 \\
Greening payment (€/hectare) & 103 & 98 & 134 \\
Total impact (millions of $€$ ) & 1.8 & 1.2 & 24.0 \\
\hline
\end{tabular}

Source: authors' elaboration on Italian FADN Database and Census Data, 2010 
The present contribution examined the role that public compensations play for the spread of green-oriented practices, showing very interesting results. In particular, we can remark that the common rules, in this case defined by greening, have very different impacts also in situation that, at the theoretical level, may look similar.

Thus, in order to avoid an excessive diversification in the impacts of the greening interventions, it would be useful to find specific solutions to rebalance the effects on the durum wheat sector in the various Italian territorial contexts, as allowed by the present regulatory framework. For the management of these new constraints, in such a wide and regionalized sector, it might also be recommended to provide local-specific RDP measures (Dwyer, 2013).

To smooth out the differences between the territories and make more effective the policy of "environmental - agricultural" introduced by the greening, the rural development measures should not be built only in the logic of voluntary instruments "substitute" to greening commitments, rather they should foster the acceptance of innovations in the cereal sector, as requested by the European regulatory framework. In this perspective, besides measures to support training in the management of diversified cropping systems (Capitanio et al., 2011), the second pillar of the CAP might help, especially in the areas of southern Italy, covering the transaction costs, including those resulting from structural adjustment, and the increased risk associated with the change in the types of product and their ability to penetrate local markets.

Waiting to know the implementing regulations proposed at national level in relation to the regional distribution of Direct Payments, the present work has underlined how a common European perspective must necessarily correspond to diversified paths not only between MS but also within the same national borders.

In particular, for productions with strong Mediterranean features, such as durum wheat, it is crucial to check in advance the potential gradient of activation of the rules, that are mostly discussed and agreed in a very different context of discussion, that of northern European areas.

Competing interests

CAP, Environment Policies, Rural Development, Farm Managment, Policies Evaluation.

\section{Authors' contribution}

FD, wrote the "Background" and "CAP greening in the CAP contest" sections. EB wrote the "The Sector of durum wheat in italy" and "Greening impact in three Italian areas specialized in wheat cultivation" and "Methods" sections. SF wrote "Methods" and "Result and Discussion" sections. All authors wrote the "Conclusion" section and read and approved the final manuscript.

\section{Acknowledgments}

The authors wish to thank Barilla G. e R. Fratelli s.p.a. for co-financing the project "Percorsi e azioni di politica agricola, introduzione di eco-innovazione e dinamiche di sviluppo nei territori rurali ad indirizzo cerealicolo" whose results are partly presented here. Our acknowledgements also go the other partners of the project which contributed to achieve the expected results: the University Consortium for Socioeconomic and Environmental Research (CURSA); Altran Italia s.p.a.

\footnotetext{
Author details

${ }^{1}$ University Consortium for Socioeconomic and Environmental Research - CURSA, Via Palestro, 24, Rome 00185, Italy. ${ }^{2}$ Department for Innovation in Biological, Agro-food and Forest systems (DIBAF), Università degli Studi della Tuscia, (Via S.Camillo de Lellis snc), Viterbo 01100, Italy. ${ }^{3}$ Department of Economics \& Management (DEIM), Università degli Studi della Tuscia, (Via del Paradiso 47), Viterbo 01100, Italy.
}

Received: 7 September 2014 Accepted: 4 June 2015

Published online: 15 July 2015

References

Abitabile C, Scardera A (2008) La Rete Contabile Agricola Nazionale RICA. INEA, Roma

Adinolfi F, De Castro P, Capitanio F, Di Falco S (2011) Building a new framework for the common agricultural policy: a responsibility towards the overall community. Eurochoices 10(1):32-36 
Brown M, Jones J (2013) The Predicted Impacts of the Proposed Greening Measures of the 2014 CAP Reform on Farming Businesses in North Cornwall. University of Warwick: 87th Annual Conference of the Agricultural Economics Society

Capitanio F, Adinolfi F, Malorgio G (2011) What ex- plains farmers' participation in rural development policy in Italian southern region? An empirical analysis. NewMedit 10(4):19-24

Cardillo C, Cimino O, Henke R (2012) Delivering public goods in agriculture: the cost of green payments for Italian farms. Paper prepared for the 126th Eaae Seminar New challenges for EU agricultural sector and rural areas. Which role for public policy? Capri (Italy)., pp 27-29

Chatellier V, Guyomard H (2013) The first pillar direct payments in the next CAP (post 2015). A French point of view. NewMedit 12(3):11-19

Cimino O, Henke R, Vanni F (2014) Greening direct payments in Italy: what consequences for arable farms? Paper presented at the EAAE 2014 Congress "Agri-Food and Rural Innovations for Healthier Societies" August 26-29, Ljubljana (Slovenia)

Cooper T, Hart K, Baldock D (2009) The Provision of Public Goods Through Agriculture in the European Union. Report Prepared for DG Agriculture and Rural Development. Institute for European Environmental Policy, London

Czekaj S, Majewski E, Was A (2013) The impact of "greening" of the Common Agricultural Policy on Polish farms' financial situation. 3rd Agrimba-Ava Congress, Buvda

De Castro P (2006) L'agricoltura in Europa: quale futuro? Agriregionieuropa 2:7

De Castro P, Adinolfi F, Capitanio F, Di Pasquale J (2012) The future of European agricultural policy. Some reflections in the light of the proposal put forward by the EU Commission. NewMedit 11(2):4-11

Diskussionspapiere, Department für Agrarökonomie und Rurale (2010) Entwicklung, No. 1205. ISTAT. National Agricultural Statistic Census, Rome

Dwyer J (2013) Transformation from sustainable agriculture: what role for the second Pillar of Cap? Bio-based and Applied Economics 2(1):29-47

European Commission (2010) The CAP towards 2020: meeting the food, natural resources and territorial challenges of the future, Communication from the Commission to the European Parliament, the Council, the European Social and Economic Committee and the Committee of the Regions Council, COM(2010) 672 final, November 18, Brussels

European Commission (2011a) Budget for Europe 2020. Communication from the Commission to the European Parliament, the Council, the European Social and Economic Committee and the Committee of the Regions Council, COM(2011) 500 final, June 29, Brussels

European Commission (2011 b) Impact Assessment. Common Agricultural Policy towards 2020. Annex 2: Greening the CAP. SEC(2011) 1153 final/2, Commission Staff Working Paper, October 18, Brussels

Frascarelli A (2014) Gli impatti aziendali della riforma della PAC 2014-2020, Agriregionieuropa, anno 10 n. 38

Garrod G (2009) Greening the CAP: how the improved design and implementation of agri environment schemes can enhance the delivery of environmental benefits. Journal of Environmental Planning and Management 52(5):571-574

Garzon I (2006) Reforming the Common Agricultural Policy: History of a Paradigm Change. PalgraveMacmillan, Houndmills

Hart K, Baldock D (2011) Greening the CAP: Delivering Environmental Outcomes through Pillar One. Institute for European Environmental Policy, London

Heinrich B (2012) Calculating the 'greening' effect: A case study approach to predict the gross margin losses in different farm types in Germany due to the reform of the CAP

Karelakis C, Zafeiriou E, Galanopoulos K, Koutroumanidis T (2013) Natural resources in Regional and Rural Development: moving from public perception to policy actions. NewMedit 12(1):56-64

Povellato A (2012) II dibattito sul Greening e l'agricoltura italiana. Agriregionieuropa, 8(29)

Rete Rurale Nazionale (2012) Studio di impatto delle proposte di riforma della PAC post 2013, l'applicazione del modello microeconomico ad alcuni settori dell'agricoltura italiana., Working Paper prepared for the Italian Agricultural Ministry (available on www.reterurale.it)

Swinnen J (2009) On the future of direct payments", paper presented at Bureau of Economic Policy Advisor (BEPA)

Vanni F, Cardillo C (2013a) The effect of Cap greening on Italian agriculture. PAGRI/IAP Politica Agricola Internazionale 3(2013):7-21

Vanni F, Cardillo C, Cimino O, Henke R (2013b) Introducing green payments in the CAP: the economic impact on Italian arable farms. Economia e Diritto Agroalimentare 1:11-29

Westhoek H, van Zeijts H, Witmer M, van den Berg M, Overmars K, van der Esch S, van der Bilt W (2012) Greening the CAP; an analysis of the effects of the European Commission's proposal for the Common Agricultural Policy 2014-2020. PBL Netherlands Environmental Assessment Agency, The Hague

\section{Submit your manuscript to a SpringerOpen ${ }^{\circ}$} journal and benefit from:

- Convenient online submission

- Rigorous peer review

- Immediate publication on acceptance

- Open access: articles freely available online

- High visibility within the field

Retaining the copyright to your article

Submit your next manuscript at $\boldsymbol{~ s p r i n g e r o p e n . c o m ~}$ 